Katarzyna Uzar-Szcześniak*

ORCID: 0000-0002-0662-2930

Ścinawa, Poland

\title{
Pedagogue in Therapy and Care Work with Person with Dementia
}

\section{Pedagog w pracy terapeutycznej i opiekuńczej z osobą cierpiącą na demencję}

\begin{abstract}
Summary: This paper is concerned with the new issue in pedagogical reflection, the role of pedagogue in therapy and care work with people suffering from dementia. The topic was analysed from a theoretical and practical perspective. Foundations for pedagogical work with persons with dementia and their caregivers described in geragogical concepts (integrative geragogy, dementagogy, personalistic geragogy, person-centred care) were the point of reference for the view on pedagogue arising from the preliminary study conducted in three care facilities. An integral approach to care and therapy in dementia was partially fulfilled in the examined environments, as reflected by the staff's attitudes to those with dementia and their care from across diverse organisational limitations.
\end{abstract}

Keywords: special geragogy; aging; dementia; pedagogue; person-centred approach to care.

* Katarzyna Uzar-Szcześniak PhD - pedagogue, therapist in Alzheimer's Centre in Ścinawa. Address: Research-Scientific-Difactic Centre of Dementia-Related Diseases, ul. Jana Pawła II 12, 59-330 Ścinawa, Poland, e-mail: katarzyna.uzar.szczesniak@gmail.com. 
Streszczenie: Artykuł dotyczy nowego zagadnienia w refleksji pedagogicznej - roli pedagoga w terapii i opiece osób z demencją. Temat został zanalizowany w perspektywie teoretycznej i praktycznej. Podstawy pracy pedagogicznej z osobami z demencją zawarte w koncepcjach geragogicznych (geragogika integratywna, dementagogika, geragogika personalistyczna, opieka skoncentrowana na osobie) stanowią punkt odniesienia dla obrazu pracy pedagoga wynikającego z badań wstępnych przeprowadzonych w trzech placówkach opiekuńczych. Integralne podejście do opieki i terapii jest częściowo realizowane w badanych środowiskach. Znajduje odzwierciedlenie w postawach personelu wobec osób chorych oraz opieki, napotyka jednak różnego rodzaju ograniczenia organizacyjne.

Słowa kluczowe: geragogika specjalna; starość; demencja; pedagog; opieka skoncentrowana na osobie.

Every scientific discipline develops according to social changes and urgent needs resulting from this process. This rule is also applicable to pedagogy, which is still changing and a growing field of scientific reflection on support of human development in every stage of life. There has been a growing interest in educational work with elderly people in recent years. Geragogy, named according to various terminological traditions e.g. English educational gerontology ${ }^{1}$, German gerontogogik or geragogi $k^{2}$, is now an established discipline. It links knowledge on ageing itself with the perspective of education and upbringing that includes people in all stages of life living in different environments and conditions. Among various geragogical topics and fields of study, the situation of old people with dementia is of particular interest. Indeed, there has been a rise of a new subdiscipline of geragogy, precisely of special geragogy ${ }^{3}$, named from German dementagogi $k^{4}$, directed towards the needs of the elderly suffering from dementia and their caregivers. This paper focusses on the role of pedagogue in the process of support for those subjects. It is based on a literature review and the ethnographic preliminary

${ }^{1}$ Frank Glendenning, "Educational Gerontology and Gerogogy: A Critical Perspectives", Gerontology \& Geriatrics Education 13 (1993): 5-21.

2 Artur Fabiś, Łukasz Tomczyk, "Geragogika w ujęciu autorów niemieckojęzycznych", Edukacja dorostych 1 (2016): 181.

3 Ibidem, 185.

4 Janina Steurenhaler, Dementagogik. Dementiell erkrankten Menschen neu und ganzheitlich begegnen (Wiesbaden: Springer, 2013). 
study of pedagogue in three different care facilities for people with dementia in Poland. The main focus that will guide the discussion is to show the integrative dimension of special geragogy (dementagogy), its interdisciplinary character, linking different fields of scientific reflection and the input of different professions in everyday therapeutic and care work with people with dementia. The following issues will be presented respectively: dementia as the contemporary social and pedagogical challenge, theoretical answers provided by special geragogy, a practical view of pedagogue according to the empirical study and finally, directions for further development of theory and practice of educational work concerning persons with dementia.

\section{Dementia as a social and pedagogical challenge}

Following the outcomes of worldwide demographic research and statements of Alzheimer's organisations (mainly NGO's), providing adequate support for people suffering from different types of dementia is an urgent need faced by contemporary societies. There are 50 million people in the world ${ }^{5}, 300-500$ thousand in Poland ${ }^{6}$ with dementia and these numbers are expected to increase in the future due to the growing number of people aged $60+^{7}$. In particular, the subpopulation of older people aged $80+^{8}$ are especially prone to develop cognitive disorders and dementia ${ }^{9}$. Currently, there is no effective causal treatment, with only symptom-revealing drugs being available, unfortunately not without side effects.

5 Alzheimer's Disease International, World Alzheimer's Report 2018. The state of the art of dementia research: New frontiers (London, 2018), 34.

${ }^{6}$ Tomasz Gabryelewicz, "Epidemiologia choroby Alzheimera", in: Sytuacja osób chorych na Alzheimera w Polsce. Raport RPO, ed. Andrzej Szczudlik (Warszawa: Biuro Rzecznika Praw Obywatelskich, 2016), 33.

7 Główny Urząd Statystyczny, Informacja o sytuacji osób starszych na podstawie badań Gtównego Urzędu Statystycznego (Warszawa, 2018), 4.

${ }^{8}$ Departament Badań Demograficznych i Rynku Pracy GUS, Ludność w wieku 60 lat $i$ więcej. Struktura demograficzna i zdrowie (Warszawa, 2016), 3.

9 Alicja Klich-Rączka, Joanna Siuda, Karolina Piotrowicz, Magdalena Boczarska-Jedynak, Anna Skalska, Ewa Krzystanek, Barbara Wizner, Maciej Świat, Michał Skrzypek, Grzegorz Opala, Tomasz Grodzicki, "Zaburzenia funkcji poznawczych u osób w starszym wieku", in: Aspekty medyczne, psychologiczne, socjologiczne i ekonomiczne starzenia się ludzi w Polsce, eds. Małgorzata Mossakowska, Andrzej Więcek, Piotr Błędowski (Poznań: Termedia, 2012), 112. 
Depending on the stage of the disease, the person suffering from dementia requires differing levels of care and support, from temporary assistance to 24-hour care. The last option, the most demanding and relatively frequent, is provided mainly by family caregivers, who are perceived as the "invisible subjects" in the care system ${ }^{10}$. In Poland, $92 \%$ of ill persons remain at home till their last days ${ }^{11}$. The necessity to combine work, home and care activities, often a weak health condition because of their own ageing (caregivers are often $65+)^{12}$, lack of the respite care and additional funds, all imply the need to develop a formal and informal network of support for ill people and their caregivers. Also, the care relationship is difficult and demanding by itself. Cognitive disorders (e.g. disorientation, forgetting, difficulties with recognising), emotional (e.g. anxiety, irritation or depression, apathy) and behavioural (e.g. wandering, aggression, disinhibition) symptoms of dementia require an adequate care response to maintain the preserved abilities of an ill person and their quality of everyday life.

There is a vast need for social, medical, economic and psychological support for informal caregivers. Unfortunately, the public system of care for people with dementia in Poland is not very well developed ${ }^{13}$. They are included in other groups of health and care receivers, without dedicated diagnostic and therapeutic solutions. There is a lack of interdisciplinary, professional facilities designed purposely for patients with dementia. There is a need for change as confirmed in Polish Alzheimer's Plan created in 2011, unfortunately still not approved by the government ${ }^{14}$. Taking into account all the mentioned conditions concerning dementia care, raises the question of pedagogical input. Is dementia also an important subject for special geragogy? Can pedagogue add or bring a broader perspective to the therapeutic process designed for persons with dementia? Is pedagogical/educational support

${ }^{10}$ Mariola Racław, “Opiekunowie nieformalni - 'niewidoczne' podmioty”, in: Publiczna troska, prywatna opieka. Społeczności lokalne wobec osób starszych, ed. Mariola Racław (Warszawa: ISP, 2011), 276.

11 Magdalena Durda, "Organizacja opieki nad osobami z demencją w Polsce na tle krajów rozwiniętych i rozwijających się”, Gerontologia Polska 2 (2010): 77.

12 Agnieszka Nowicka, “'Zespół opiekuna’ jako konsekwencja sprawowania długotrwałej opieki nad osobą z otępieniem typu Alzheimera”, in: Człowiek z choroba Alzheimera w rodzinie i środowisku lokalnym, eds. Agnieszka Nowicka, Wioletta Baziuk (Zielona Góra: Oficyna Wydawnicza UZ 2011), 153.

13 Durda, Organizacja, 83.

${ }^{14}$ Lubuskie Stowarzyszenie Wsparcia Opiekunów i Osób Dotkniętych Chorobą Alzheimera, Informacja prasowa-XXZjazd Organizacji Alzheimerowskich (Zielona Góra, 2018), 1. 
useful for professional and informal caregivers? What kind of competences are necessary for the pedagogue working with people with dementia?

Those and other questions have been initially reflected on the basis of geragogical theory. It is possible to indicate a few theoretical concepts that provide foundations for therapeutic practice directed to persons with dementia that can be conducted by pedagogues, thereby providing an integrative approach to those with dementia and the system of care and support. The German concept of integrative geragogy by Peter Mederer and Alexander Skiba emphasises the multidimensional aspect of pedagogical interventions designed for old people with disabilities. Integration described as "the concreative development of persons and spheres during psychomotor and social interventions" 15 is the core component of the whole pedagogical process. Integrative geragogy aimed at maintaining competences, protecting of life quality and life-satisfaction ${ }^{16}$ is intended for old people with various types of disabilities, including dementia. It concerns all dimensions of human life, embraces all environments involved in the process of care and involves the cooperation between disciplines like social work, special needs education, education, gerontology, andragogy, nursing, occupational therapy and medicine. The integrative geragogy approach also considers the biological frames of development, genetic equipment and neuronal plasticity, their potentials and limitations, emphasising the role of social relations between the senior and the environment; it puts the old person in the centre around which all geragogical interventions are focused ${ }^{17}$.

It is also worth to refer to the already mentioned concept of dementagogik by Steurenhaler. The author derives the meaning of the term from two German words demens "with limited presence" and agogik "to lead/ guide" 18 . The final meaning of dementagogik is to accompany people with dementia in professional, pedagogical way, to be with them when they experience their mind fading away and have the feeling that their personality and dignity is going away ${ }^{19}$. The receivers of dementagogical support are not

15 Peter Maderer, Alexander Skiba, "Integrative geragogy: Part 1: Theory and practice of a basic model”, Educational Gerontology 32 (2006): 137.

16 Ibidem, 136.

17 Peter Maderer, Alexander Skiba, "Integrative geragogy: Part 2: Interventions and legitimizations", Educational Gerontology 32 (2006): 156-157.

${ }^{18}$ Not direct, metaphoric translation. German "demens" meaning "ohne Geist" can be also translated as "without spirit or mind".

19 Steurenhaler, Dementagogik, 93. 
only old people with dementia but also younger people, who also may suffer from it (genetically conditioned dementia that affects people in their 30's; people with intellectual disabilities who are much more prone to develop dementia symptoms earlier). Pedagogical interventions for persons with dementia should be directed by the following aims: 1) to fulfil their basic needs, 2 ) to discern the personal dimension of human with dementia, to acknowledge, promote and maintain dignity, 3) to provide the sense of security and confidence, necessary to sustain the psychological balance, 4) to maintain their independence and personal responsibility, 4) to support the family and caregivers in professional care and communication with an ill person ${ }^{20}$. Practically, the work of dementagogue will consist of care and therapy with persons with dementia, support, counselling, education and training for families and care workers, advocacy of social and legal solutions that improve the situation of ill persons and their relatives. The concept of dementagogik has strong theoretical frames (references to medicine, psychology, philosophy) and includes diverse practical applications from different pedagogical fields (physical and health education, social and cultural pedagogy, art education) that concern different environments (family, institutions) and stages of life (from raising awareness and prevention starting from childhood till support and care in adulthood and old age).

The idea of pedagogical support in dementia is also found in works of Polish pedagogues. The wide theoretical background for it is set in personalistic concept of geragogy by Katarzyna Uzar-Szcześniak, whereby all supportive, educational and upbringing interventions in old age, including ageing with disabilities, should be referred to the basic truth on the personal dimension of human. The case of dementia creates the particular chance and challenge to recognise and affirm the dignity of an ill person. In this concept, human dignity has an ontological status that allows it to be preserved regardless of changing conditions of age, health, physical and mental abilities. Paradoxically, dementia reveals the essence of a human being that becomes a reason for all the support and care relationships ${ }^{21}$. To be with a person with dementia, maintain the contact, respect their dignity and autonomy, recognise and fulfil their needs, as well as create a caring environment are the main

${ }^{20}$ Ibidem, 94-97.

${ }^{21}$ Katarzyna Uzar, Wychowanie w perspektywie starości. Personalistyczne podstawy geragogiki (Lublin: Wydawnictwo KUL, 2011), 116-117. 
tasks for person-oriented pedagogue ${ }^{22}$. Similar statements are also found in Tom Kitwood's theory of person-centred care in dementia ${ }^{23}$. The idea of valuing persons with dementia and caregivers, treating them individually, looking at the world from their perspective and creating positive social environment to maintain their life quality ${ }^{24}$ are core indicators of well delivered care interventions in informal and institutional settings. The difference between personalistic geragogy and person-centred care concerns the theoretical background. For the former, it is personalistic philosophy and pedagogy for the latter Roger's psychology and Martin Buber's philosophy ${ }^{25}$. However, the person-centred care approach might be perceived as a more practical application of the personalistic geragogy theory.

More detailed implications for pedagogical practice concerning people with dementia are delivered in works of Adam Zych and Marlena Kilian. The need for the development of special geragogy in general and dementagogy in particular is based on the following arguments. Disability is a common fact among old people and special needs resulting from it are not sufficiently acknowledged in the education offered for the elderly ${ }^{26}$. There is a growing demand for professionals working with this group of receivers who participate in interdisciplinary teams providing properly adjusted, holistic care and support for old people with disabilities and their caregivers. The aim of special geragogue would be to make an old and disabled persons' existence a dignified and valuable stage of life ${ }^{27}$. The detailed tasks of dementagogy would be to diagnose the situation and needs of people with dementia, create space for close relationships, social integration and a safe environment, develop methods and means of systemic, integrated support, inform and advise patients and caregivers on solving problems and accessible forms of support, linking

${ }^{22}$ Katarzyna Uzar-Szcześniak, "Personalistyczna perspektywa starości i jej implikacje dla pedagogii osoby", Forum Pedagogiczne 2 (2015): 87.

${ }^{23}$ Tom Kitwood, Dementia reconsidered. The person comes first (New York: Open University Press, 2013).

${ }^{24}$ Dawn Brooker, "What is person-centred care in dementia?", Reviews in Clinical Gerontology 13 (2003): 216.

${ }^{25}$ Kitwood, Dementia, 10.

${ }^{26}$ Adam A. Zych, "Pedagogika osób z otępieniem jako nowy obszar geragogiki specjalnej”, Labor et educatio 2 (2014): 277.

27 Adam A. Zych, "Geragogika specjalna - potrzeba, konieczność, czy moralny obowiązek?”, in: Pedagogika społeczna w stużbie rodziny (aspekt marginalizacyjny, resocjalizacyjny i psychologiczny), eds. Krzysztof Gąsior, Tadeusz Sakowicz (Kielce: Świętokrzyskie Centrum Profilaktyki i Edukacji, 2005), 53. 
those in need with institutions and subjects, assess abilities of ill persons and work on their personal resources to maintain their everyday activities and the sense of self-agency ${ }^{28}$. The role of special pedagogue is to integrate all possible resources of support, all professionals working with persons with dementia and all environments they live $i^{29}$. This demanding task can be realised only by well prepared and educated workers who have knowledge of dementia and its symptoms, can describe the situation of particular person suffering from this disease and adjust suitable forms of support to their needs.

To summarise basic information on dementia and its social impact as well as statements of geragogical theory, one may draw the following implications significant for pedagogue working in this field: 1) the centre of pedagogical work is the person with dementia with dignity, identity and autonomy, implying that all forms of therapy and support should by highly individualised and personalised; 2) an integrative, holistic approach in terms of human structure (physical, mental, spiritual, social aspect) and life and care (home, local community, institutions) environments is the core rule of pedagogical work with people with dementia; 3 ) the process of guidance and support for ill people requires professional preparation, that is, knowledge, experience and suitable skills; 4) pedagogue can work in different occupational frames, caregiver, therapist, educator, trainer, or counsellor in different dementia care and support settings; 5) the main aim of geragogical work is to enable the person with dementia and caregiver to live a dignified life as long as it is possible, taking into account preserved abilities and accessible resources of support.

\section{Pedagogue work with elders with dementia - practical exemplification}

This part of paper attempts to compare theoretical assumptions of geragogical theory with the experience of work in care facilities for persons with dementia. It is based on preliminary research framed in an ethnographic scheme, based on direct therapeutic work with the elderly as a therapist, on participatory observation and semi-structured reviews with staff. The eth-

${ }^{28}$ Zych, "Pedagogika", 278-280.

${ }^{29}$ Marlena Kilian, "Geragogika specjalna w dobie starzenia się społeczeństw”, in: $D y$ lematy (niepetno)sprawności - rozważania na marginesie studiów kulturowo-społecznych, eds. Marzena Dycht, Lidia Marszałek (Warszawa: Wydawnictwo Salezjańskie, 2009), 320. 
nography is "the art and science focused on the description of human group its institutions, interpersonal behaviours, material works and beliefs" ${ }^{30}$. The researcher becomes the part of the environment, blends in it, recognises and follows the community rules and does the same activities as the group members. An ethnographical approach allows insight of the view on the community and interactions in it from the perspective of its participants ${ }^{31}$. The final outcome of the research is the conjunction of their attitude expressed in words, behaviours, convictions with the researcher's experience as the community participant compounds with research aims and assumptions. This scheme was followed in the described project. The researcher entered examined facilities as the fresh employer or volunteer with the intention of work and research, that was not an easy task to combine. Barriers appeared, especially when work colleagues, after some period of cooperation, were asked to participate in interviews, for example, anxiety of being judged or have their personal opinions published appeared. Assurance of anonymity and only for the scientific aims, as well as descriptive use of the data overcame those difficulties and allowed for gathering sufficient information. Also, the agreement for the participation in the research and publishing their outcomes was obtained from directors of facilities and from the elderly living there.

The main aim of the research, situated in the special education humanistic paradigm ${ }^{32}$, was to describe the role of pedagogue in care and therapy with persons with dementia. The research was conducted between October 2013 to September 2018 in three different settings: day care (43 participants in total, 30 with mild to moderate cognitive disorders), long term care (63 participants in total, 20 with cognitive disorders, both facilities in social care sector) and short term, diagnostic treatment (90 participants with various cognitive and behavioural disorders, facility in the health care sector). Each phase of research conducted by the researcher, the author of this paper, lasted between 4-8 months, the reviewed workers were six informants, of which three had pedagogical higher education (special education, social work) and

${ }^{30}$ Michael Angrosino, Badania etnograficzne i obserwacyjne (Warszawa: PWN 2010), 44.

31 Tadeusz Pilch, Teresa Bauman, Zasady badań pedagogicznych. Strategie ilościowe i jakościowe (Warszawa: Żak, 2010), 294.

${ }^{32}$ It accentuates: complementary character of qualitative and quantitative research methods; interpretative understanding of disability in her socio-cultural aspect; individualization, empowerment and normalization trends in relationships with persons with disability [Amadeusz Krause, "Niepełnosprawność - Inny w paradygmacie humanistycznym", Niepetnosprawność 4 (2010): 118]. 
three had vocational education (medical care, occupational therapy). Their work experience ranged from 6 months to 8 years. The inclusion criteria were for facilities, the different type of care and therapy delivered to people with dementia (day, short and long term), and for interviewees, pedagogical education and the type of work carried out in the facility (non-pharmacological therapy interventions).The research results were based on: 6 interviews (around 20 pages of transcription), notes in the observation diary conducted depending on the facility, each work day (October 2013 -February 2014 in the long term care facility, January 2018 - September 2018 in the short term diagnostic facility) or every two work days per week (October 2013 - February 2014 in the day care facility) and documentation of therapeutic work (admission forms, care and therapy plans, descriptions of therapeutic interventions) in reference to the work of pedagogues in the first instance. However, observation and interviews with other specialists allowed a more complex insight into the role of pedagogue in care and therapy with persons with dementia.

All data collected were analysed by the author with the use of a coding procedure ${ }^{33}$ based on descriptive categories arising from the following detailed research questions ${ }^{34}$ : what are duties and tasks of pedagogue working in examined facilities? (category: everyday work description), what is the place of pedagogue in the care and therapy team? (category: the role of pedagogue in the therapy team), what are his competencies? (category: hard [for e.g., education, vocational training] and soft [for e.g., personal traits, interpersonal skills] hold and desirable competencies of pedagogue), what are subjectively perceived advantages and difficulties of the therapeutic work of pedagogue with people with dementia? (category: advantages and challenges of therapeutic work of pedagogue). The perspective of interpretation was set by the person-centred approach to care and therapy in the dementia, described in the theoretical part of the paper. In summary, the general aims of this research were 1) to assess and describe the specificity of pedagogue's work with persons with dementia and 2) to determine if it reflects the person-centred perspective in dementia care and therapy. Obtained data and conclusions drawn from them cannot be generalised and concern subjective perspective of work with persons with dementia in examined facilities. However, they provide an initial insight in geragogical work in this relatively new field, which could be the subject of further, more extended research.

33 Jeane W. Anastas, Research Design for Social Work and the Human Services (New York: Columbia University Press, 1999), 419.

${ }^{34}$ David Silverman, Prowadzenie badań jakościowych (Warszawa: PWN, 2010), 83. 
To determine the specificity of pedagogue's work in this field, one should begin with the description of the job positions and duties held by the examined staff, five of whom worked as occupational therapists and one as the manager of the therapy team. Depending on the position and organisational scheme of the facility, they fulfilled diverse tasks connected with everyday care and therapy, from personal hygiene, help with feeding, cleaning, through to different types of therapy, such as cognitive (reality orientation, reminiscence, memory training), arts \& crafts, music, dance, movement and exercise, relaxation, walking, games, social and cultural events, conducted individually and in groups, to management, creating care and therapy plans, participation in care team and work with seniors' documentation. It is evident that work of pedagogue/therapist is very diverse, requiring complex skills, acceptance of entrusted duties, and good team cooperation.

The main challenges and rewards of this kind of work were revealed. Observation and interviews' material indicated that the specificity of the disease and its symptoms imply various demands and difficulties to overcome. Agitation, resistance, withdrawal, changing mood of ill persons require an appropriate response from the therapist who must find the right way to communicate and motivate them to engage in activities. Worsening physical and cognitive state of patients is one of the most challenging aspects, as it puts to the test the basic aim of therapy, the improvement in the actual state of a person. Within the dementia context, the scope of development and positive change in everyday functioning are often limited, contradictory to educational and therapeutic interventions directed to children and young people (even in the field of special education), where for example, the zone of the proximal development indicates abilities that might improve as a result of therapy. In working with people with dementia, the focus is typically on maintaining preserved skills and the development means often no regression. The aim of therapy must be different than the efficacy. Situated in the sphere of human dignity, highest possible life quality also requires special competences from the therapist, who should be able to notice and acknowledge the human dimension of dementia, regardless of its physical and psychological limitations. In practice, this means to agree on the transience of therapeutic effects, to value the "magic moments" of a person's conscience and vivid communication that sometimes appear only occasionally, to accept the actual state of the patient, engaging them in activities adjusted to their abilities.

Support might be the reference to the patient's biographical and medical information as important facts regarding the person's life that may provide tips for planning and conducting therapeutic activities, allowing communica- 
tion to be established and maintained, even if it is only in a non-verbal form. However, cooperation with other specialists is not always easy, because of the division between different sectors (e.g., medical and care/therapeutic) emphasised by staff, but necessary to form the interdisciplinary team who share information and support each other in person-centred care. Also, suitable competencies gained from education and previous voluntary and vocational experience facilitate therapeutic work. Knowledge of dementia, its causes and symptoms, on methods and forms of therapy was perceived by the staff reviewed as necessary but not sufficient to work in that field. They questioned, in some way, the value of a theoretical approach in academic education and emphasised the necessity of practical work experience in different care and therapy settings for longer than a few days. They regarded the person with dementia as the best teacher and emphasised the dynamic nature of the work, that one should be constantly open to new information on the patient as well as new therapeutic solutions. The soft type competencies were also emphasised, such as specific personality traits like patience, composure, respect, positive approach to ill persons, to have "something" that opens you up to work with the elderly who are very sensitive and easily verify the caregiver/therapist approach. All those features can be included in altruistic motivation, where giving outweighs receiving, however certain, often unmeasured, benefits result from that type of work.

To observe seniors' satisfaction from acting independently, to see their pleasure and smile, to sense their feeling of belonging and being valued, became measures of effective therapy. Also, to learn from the wisdom of old people and being appreciated by them reinforced the motivation and sense of work. The rewards included their satisfaction from help provided for caregivers, the relief they got from everyday care duties. One of study participants emphasised that the advantage of her work was "dedication to old people in order to enable them to live with dignity in last years of life, being needed, loved and appreciated, despite cognitive and physical limitations". This statement directly indicates the person-oriented approach to therapy and care which corresponds with assumptions of the geragogical theory described previously. This demanding and difficult work needs deeper justification, referring to the essence of human life, for some reasons not always recognised but present in the existence of persons with dementia ${ }^{35}$. The dia-

35 John Killick, "Magic Mirrors. What People with Dementia Show us about Ourselves", in: Ageing, Spirituality and Well-being, ed. Albert Jewell (London: Jessica Kingsley Publishers, 2004), 148. 
lectic of struggle and sense observed in the human aspect of care is reflected in messages sent by interviewed staff to future therapists: "it is worth to consider if you want to do this job because its complicated character", "you have to have suitable features of personality and calling to do it, education is not enough", "you have to like what you do, seniors feel exactly what is your approach to them", "if smile, and joy from little steps is enough for you, this job is for you"; one person used the Albert Sweitzer's quote "have heart and look into heart" as an important clue to therapeutic work.

\section{Conclusions and implications for future geragogical practice}

The initial insight into the role of pedagogue with people with dementia gained from preliminary studies conducted in different care and health facilities revealed basic facts concerning this new educational and therapeutic field in a Polish context. From the subjective perspective of a therapist, it is difficult and demanding work, mainly because of the progressive character of dementia that limits the chances for developmental improvements. It requires a wide scope of competencies not limited to medical, psychological and methodological knowledge. Even more important are soft skills concerning personality, communication and motivation to work with elderly people with cognitive disorders. Indeed, one might say that a special "calling" is required for this kind of work, that is based on recognition and acknowledgement of the deep human dimension of dementia and on a willingness to accompany and support people suffering from it. Crucial is also the prior experience gained in direct work with people with disabilities and seniors in care and health facilities that allows the future specialist to check one's own resources and learn from practice; Dewey's "learning by doing" approach is an exact application. Observations made during the ethnographic research also indicated creativity as the remedy for daily routine and rarity of visible therapeutic effects. Thoroughness and "fresh view" during diagnosis and observation of patient's behaviour, empathy in recognising their needs and feelings, unceasing search for new methods and solutions adjusted individually to person's abilities, introduce work dynamics, preventing feelings of helplessness, aimlessness and burn out, especially when it is enhanced by team cooperation and exchange of information and experience.

From an organisational perspective, the position of pedagogue seems not to be specified precisely. From the research findings, working in posi- 
tions of occupational therapist or caregiver in the Polish social and health system does not require higher pedagogical education. It is the result of the lack of adequate legal regulations that will determine the role of pedagogue in care settings for the elderly: its receivers, places, type of educational and vocational preparation. To provide them seems to be an important task for social policy faced with an ageing society and growing number of people suffering from dementia. Another significant issue is the individualisation of therapeutic interventions and adjusting them to the needs and abilities of an ill person. Ageing is the most individualised out of life period, particularly in the case of dementia, when biographical knowledge can gradually go away along with memory loss. To catch memories, get to know the family and occupational history, find out about daily life preferences, favourite leisure activities etc. is often crucial for identifying the most appropriate therapeutic activities. Also, medical and psychological information on the patient's state allows activities to be adjusted to suit their abilities.

Such as individualised approach requires a sufficient number of staff, a condition that is not often fulfilled in care facilities. It is especially difficult during work group when participants need constant repetitions, have hearing or sight problems. Making the proper diagnosis, planning the therapeutic process, and working individually with old person requires much time, therefore is not often possible in care facilities. Nonetheless, individual therapy schemes were implemented in the facilities examined in this study. The egalitarian model of management of therapy team, where every worker had similar duties seemed to be more effective. Sharing the same responsibility and exchange work activities favoured cooperation between staff, where an open style of communication and solving problems was also employed. In some facilities, the division between medical and therapy/care level was noticeable and lack of collaboration hindered effective work. One of reviewed staff pointed out the need to enhance the role of non-drug therapy in dementia treatment and balance it with the medical perspective. This clearly indicates the need for a holistic approach to dementia care at an organisational level.

In conclusion, the practice of pedagogical work with people with dementia follows, at least partially, the theoretical assumptions on person-centred care and support formed from a geragogical point of view. Statements of reviewed staff, observations and therapeutic work in the examined facilities indicated that they have an intuitive understanding of dignity in dementia and want to support those who suffer from it, enabling them to maintain the best possible quality of life. However, the operational sphere of their work has only started to change. Their status needs the appropriate assessment in 
the map of occupations directed towards the elderly. Indeed, the system they work in needs coordination, cooperation between different specialists and an integrative approach to patients and caregivers. More professional staff are required do provide individualised support and indicated needs should be addressed by structural, organisational and financial changes in the health and care system. Appropriate theoretical foundations based on special geragogy require practical support from the state as well as social and health policy makers.

Nonetheless, the most important aspect of the work of pedagogue with persons with dementia is care for the relationship. The strong emphasis identified in Tom Kitwood's work, when he quotes Martin Buber: "All real living is meeting" 36 . To be in a deep relationship allows one to live with dignity, regardless of any cognitive or other limitations. One of the strongest needs of people with dementia is to be in a relationship, to feel needed, loved and respected. Any form of treatment or therapy including pedagogue's work, deprived from the dimension of human relationship, would be only the work with disease (person-with-DEMENTIA), not with the person who indeed suffers from a cognitive disorder (PERSON-with-dementia) ${ }^{37}$ but still has human dignity that can be acknowledged only by another person.

\section{Bibliography}

Alzheimer's Disease International. World Alzheimer's Report 2018. The state of the art of dementia research: New frontiers. London, 2018.

Anastas, Jeane W. Research Design for Social Work and the Human Services. New York: Columbia University Press, 1999.

Angrosino, Michael. Badania etnograficzne i obserwacyjne. Warszawa: PWN, 2010. Brooker, Dawn. "What is person-centred care in dementia?". Reviews in Clinical Gerontology 13 (2003): 215-222.

Departament Badań Demograficznych i Rynku Pracy GUS. Ludność w wieku 60 lat i więcej. Struktura demograficzna i zdrowie. Warszawa, 2016.

Durda, Magdalena. "Organizacja opieki nad osobami z demencją w Polsce na tle krajów rozwiniętych i rozwijających się". Gerontologia Polska 2 (2010): 76-85.

Fabiś, Artur, Łukasz Tomczyk. „Geragogika w ujęciu autorów niemieckojęzycznych". Edukacja dorostych 1 (2016): 181-188.

\footnotetext{
${ }^{36}$ Kitwood, Dementia, 11.

${ }^{37}$ Kitwood's differentiation - Dementia, 7.
} 
Gabryelewicz, Tomasz. "Epidemiologia choroby Alzheimera”. In: Sytuacja osób chorych na Alzheimera w Polsce. Raport RPO, ed. Andrzej Szczudlik, 33-34. Warszawa: Biuro Rzecznika Praw Obywtelskich, 2016.

Glendenning, Frank. "Educational Gerontology and Gerogogy: A Critical Perspectives". Gerontology \& Geriatrics Education 13(1993): 5-21. DOI: 10.1300/J0 21v13n01_02.

Główny Urząd Statystyczny. Informacja o sytuacji osób starszych na podstawie badań Głównego Urzędu Statystycznego. Warszawa, 2018.

Kilian, Marlena. “Geragogika specjalna w dobie starzenia się społeczeństw”. In: $D y$ lematy (niepetno)sprawności - rozważania na marginesie studiów kulturowo-społecznych, eds. Marzena Dycht, Lidia Marszałek, 316-341. Warszawa: Wydawnictwo Salezjańskie, 2009.

Killick, John. "Magic Mirrors. What People with Dementia Show us about Ourselves". In: Ageing, Spirituality and Well-being, ed. Albert Jewell, 143-152. London: Jessica Kingsley Publishers, 2004.

Kitwood, Tom. Dementia reconsidered. The person comes first. New York: Open University Press, 2013.

Klich-Rączka, Alicja, Joanna Siuda, Karolina Piotrowicz, Magdalena Boczarska-Jedynak, Anna Skalska, Ewa Krzystanek, Barbara Wizner, Maciej Świat, Michał Skrzypek, Grzegorz Opala, Tomasz Grodzicki. "Zaburzenia funkcji poznawczych u osób w starszym wieku". In: Aspekty medyczne, psychologiczne, socjologiczne i ekonomiczne starzenia się ludzi w Polsce, eds. Małgorzata Mossakowska, Andrzej Więcek, Piotr Błędowski, 109-121. Poznań: Termedia, 2012. Krause, Amadeusz. "Niepełnosprawność - Inny w paradygmacie humanistycznym". Niepetnosprawność 4 (2010): 111-121.

Lubuskie Stowarzyszenie Wsparcia Opiekunów i Osób Dotkniętych Chorobą Alzheimera. Informacja prasowa - XX Zjazd Organizacji Alzheimerowskich. Zielona Góra, 2018.

Maderer, Peter, Alexander Skiba. "Integrative geragogy: Part 1: Theory and practice of a basic model". Educational Gerontology 32 (2006): 125-145.

Maderer, Peter, Alexander Skiba. "Integrative geragogy: Part 2: Interventions and legitimizations". Educational Gerontology 32 (2006): 147-158.

Nowicka, Agnieszka. “'Zespół opiekuna’ jako konsekwencja sprawowania długotrwałej opieki nad osobą z otępieniem typu Alzheimera". In: Człowiek z choroba Alzheimera w rodzinie i środowisku lokalnym, eds. Agnieszka Nowicka, Wioletta Baziuk, 153-171. Zielona Góra: Oficyna Wydawnicza UZ, 2011.

Pilch, Tadeusz, Teresa Bauman. Zasady badań pedagogicznych. Strategie ilościowe i jakościowe. Warszawa: Żak, 2010. 
Racław, Mariola. "Opiekunowie nieformalni - 'niewidoczne' podmioty". In: $P u$ bliczna troska, prywatna opieka. Spoleczności lokalne wobec osób starszych, ed. Mariola Racław, 275-285. Warszawa: ISP, 2011.

Silverman, David. Prowadzenie badań jakościowych. Warszawa: PWN, 2010.

Steurenhaler, Janina. Dementagogik. Dementiell erkrankten Menschen neu und ganzheitlich begegnen. Wiesbaden: Springer, 2013.

Uzar, Katarzyna. Wychowanie w perspektywie starości. Personalistyczne podstawy geragogiki. Lublin: Wydawnictwo KUL, 2011.

Uzar-Szcześniak, Katarzyna. "Personalistyczna perspektywa starości i jej implikacje dla pedagogii osoby". Forum Pedagogiczne 2 (2015): 77-93.

Zych, Adam A. "Geragogika specjalna - potrzeba, konieczność, czy moralny obowiązek?”. In: Pedagogika spoleczna w stużbie rodziny (aspekt marginalizacyjny, resocjalizacyjny i psychologiczny), eds. Krzysztof Gąsior, Tadeusz Sakowicz, 53-60. Kielce: Świętokrzyskie Centrum Profilaktyki i Edukacji, 2005.

Zych, Adam A. "Pedagogika osób z otępieniem jako nowy obszar geragogiki specjalnej". Labor et educatio 2 (2014): 271-283. 
